\title{
Virtual E-Learning Media to Improve Vocational School Students' Learning Outcome
}

\author{
Fanni Rahmawati ${ }^{1}$, Baedhowi ${ }^{1}$, Lukman Hakim ${ }^{1}$ \\ ${ }^{1}$ Master's Degree Program in Economics Education SebelasMaretUniversity,Surakarta, \\ Indonesia \\ fanniraa@gmail.com
}

\begin{abstract}
The aim of this article is to know whether the use of virtual e-learning media can improve vocational school students' learning outcome. This article is written by reviewing relevant literature. The problem faced in teaching vocational school students is the use of traditional method in which the teacher does not use various teaching materials. Regarding this, the students face difficulty in understanding the materials. This obviously impacts the students' learning outcome. The teaching learning process that involves ICT (Information and Communication Technology) is seen as a solution that facilitates the students to learn actively and understand the materials better. One of the ICT media that can be implemented is virtual e-learning media. The teaching learning process done through website is one example of e-learning. By utilizing elearning, the students are able to learn individually either inside or outside the classroom (e.g. on job training). The use of virtual e-learning is more effective and efficient so that it will improve vocational school students' learning outcome.
\end{abstract}

Keywords: e-Learning; learning outcome; virtual learning media; vocational school

\section{INTRODUCTION}

Along with science and technology advancement, the quality of education should be improved since education is an institution in which human resources are developed. Education is not only the process of learning inside the classroom. There are formal, non-formal, and informal educations. Vocational school is an example of formal education. It is a type of school in which students learn on a certain field. By focusing to learn on a certain field, students are expected to have qualified and specific skill. When they acquire the skill, they will be ready to be employed. However, in fact, the unemployment rate of vocational school graduates is still high. Based on central bureau of statistics BPS [1] there are 19.19\% (1.383.022) of unemployment which are considered as educated unemployment (SMA, SMK, and higher education graduates). 
In order to improve students' outcome; improvement, innovation, and modification on every learning aspect is needed. Teaching and learning process that involves information and communication technology (ICT) is one of several ways that can facilitate students' active learning. In order to implement technology-based learning, the teacher can develop learning media. Learning media is a tool that helps teachers to assist students in understanding the material. Not only helping students to understand the material, learning media can be used to provide students new and various learning experiences. Moreover, it can be used to attract students' interest.

\section{Virtual Learning Media}

The need of learning innovation can be satisfied through developing learning media. One of learning media that teachers can use is virtual media. As stated by Xiao [2] implementing learning media to enrich students' learning experiences has been a focus of many researchers. Based on this statement, it is justified that virtual media is a media that can support students to understand learning material in an effective and efficient way. In line with Xiao, Parson \& Bignell[3] asserts that virtual media generates efficient learning. This happens since virtual media helps students to learn many things effectively. By implementing virtual media, teachers at the same time promote social networking, entertainment, business activities, and education. Moreover, Burgess \& Ice [4] state that virtual learning is helpful to improve students' individual knowledge. Hence, virtual media is an innovation that facilitates education.

According to Smaldino et al. [5] virtual media has both advantages and disadvantages. Virtual media is safe and communicative. Moreover, it offers students more learning opportunities. However, virtual media is costly, complex, and limited. Another advantage of virtual media is that it strengthens learning concepts inside the classroom Bojanova\& Pang[6] Besides, by implementing virtual media, the learning cost can be minimized Widarto \& Latiff, [7] states that virtual learning can minimize learning cost since the learning process can be done not only inside but also outside the classroom.

As stated by Bojanova \& Pang [8] the purposes of developing virtual media are accomplishing pedagogical goal and generating interesting and interactive learning that can support students in getting more learning experiences. Parson \&Bignell[9] state that virtual learning eases the learning process. The easier learning process will improve students' ability to understand the material. While students' ability to understand the material improves, the expected learning outcomes will be achieved.

\section{E-Learning}

Horton [10] defines e-learning as "the use of information and computer technologies to create learning experiences". Regarding the definition, e-learning is a learning process that makes use any information and computer technology. E-learning process creates learning experiences. In addition, Hartley [11] states that e-learning is a teaching learning process that enables students to learn by using internet, intranet, or other 
computer networks. E-learning is also known as online learning, virtual learning, distributed learning, and networked or web-based learning.

By implementing e-learning, there will be a shift from teacher-centered to studentcentered learning. E-learning allows students to access accurate and up-to-date information related to the material. Moreover, students are also able to access any information easily everywhere and every time without limitations. Therefore, e-learning is an innovation that the teacher can use as a learning media.

\section{Students' Learning Outcome}

Rusman [12] defines learning outcome as a number of experience obtained by students on the cognitive, affective, and psychomotor fields. According to Tagg [13] learning outcome is a long-term goal of a teaching and learning process. Learning outcome is obtained through teaching and learning process and the assessment of the process itself.

Factors affecting students' learning outcome according to Sadirman [14] are the success of the teacher in managing the class, the applied method, learning media, learning sources, and the students themselves. The educational formulations of national educational system both the purpose of curriculum and instructional purpose use learning outcome classification.

Tagg [15] stated that through learning outcome, learning custom can be renewed as long as it is as per to the advance of technology. The development of learning media is one of the renewal matters in learning or an innovation in it. This development is hoped to be an innovation that can escalate students' learning outcome. In line with Tagg's statement, Kettunen, Mertanen, Penttila [16] said that innovation in learning is aimed to improve students' learning outcome which emphasizes on the students' cognitive, affective, and psychomotoric aspects.

\section{Vocational High School}

The definition of vocational high school according to Nagle [17] is an education with the purpose to produce skillful graduates. Hoffman and Schwarts [19] stated that vocational high school is a high school program to prepare students to get their best careers in various work fields, such as high-advanced technology-related job, service providers, health, entrepreneur, and traditional handcraft. Clarke and Winch [20] asserted that vocational high school is to prepare students to deal with working experience.

Furthermore, Gasskov [21] expounded that vocational high school has to teach several basic skills as well as special skills for each individual that can ease them to get a job or establish their own entrepreneurship, work productively, and adapt to the technological change, task, and working environment. Vocational high school collaborates with factories that are appropriate to the programs they provide based on the curriculum [22]. Collaboration between education and training is now getting more 
popular and applicable to develop students' skills and social competence in every level of training [23].

\section{E-Learning-based Virtual Learning Media to Improve the Vocational High School Students' Learning Outcome}

Based on the expounding above, e-learning-based virtual media development is needed in order to solve learning problems and improve the quality and efficacy of learning as well as to help students to do independent learning. Eventually, the students' learning outcome can be improved. According to Gregory [24], students' learning outcome has to be considered on the lesson plan. Virtual media can be alternative to students' learning. Virtual-media-based learning-outcome is an integration of technology as a means of learning and used to raise awareness towards innovation on ICT and its potential to improve students' learning quality.

Based on a research conducted by Gregory [25] the use of virtual media is regarded as an innovation in students' learning development. Virtual media enable teachers to show the teaching material as it is even without their presence in the classroom. This finding is supported by the result of research conducted by Swandi, A. Hidayah. Irsan [26] which shows that the students' learning effectiveness is more than $85 \%$ on whom virtual learning media is applied, also $93.5 \%$ students agree on the use of Lab-Virtual media in learning physics.

Based on those research findings, it can be understood that virtual media can be used as an alternative to learning that can improve students' learning outcome. Virtual media are suitable means to ensure students' learning outcome. E-learning is one of the available supports in learning besides developing virtual media based learning. Xiao [27] added that the use of virtual reality panoramas and other technologies alike show a new trend in creating and sharing various contents online.

\section{CONCLUSION}

Based on the above literature study, it can be concluded that vocational high school students need an innovation in learning, and the use of learning media is one possible answer to improve students' learning and practice quality. E-learning based virtual media can bring an innovative learning for vocational high school teaching and learning process by which significant improvement of students' learning outcome can be grasped. 


\section{REFERENCES}

1. $\quad$ BPS. (2016). Pengangguran Terbuka Menurut Pendidikan Tertinggi yang Ditamatkan 19862016. Diakses pada https://www.bps.go.id/linkTabelStatis/view/id/972.

2. Xiao, D.Y. (2000). Experiencing the library in a panorama virtual reality environment. Library Hi Tech. Vol. 18 Iss 2 pp. 177- 184

3. Parson, V. \&Bignell. S. (2011). Using Problem-Based Learning within 3D Virtual Worlds. In Transforming Virtual World Learning. Vol. 4 pp. 241-261.

4. Burgess, M.L. \& Ice, P. (2011). Using the Community of Inquiry (CoI) Model and Bloom's Revised Taxonomy to Support 21st Century Teaching and Learning in Multi-User Virtual Environments. In Transforming Virtual World Learning. Vol. 4 pp. 163-186.

5. Smaldino S.E., Russell J.D, Heinich, R. and Molenda M. (2005). Instructional Technology and Media for Learning (8ed). New Jersey: Merrill Prentice Hall

6. Bojanova, I. \& Pang. L. (2011). Enhancing Graduate Courses through

7. Widyarto, S.\&Latiff, M.S.A. (2007). The Use of Virtual Tours for Cognitive Preparation of Visitors: A Case Study for VHE. Facilities. Vol. 25 Iss 7/8 pp. 271-285

8. Bojanova, I. \& Pang. L. (2011). Enhancing Graduate Courses through

9. Parson, V. \&Bignell. S. (2011). Using Problem-Based Learning within 3D Virtual Worlds. In Transforming Virtual World Learning. Vol. 4 pp. 241-261.

10. Horton, William and Horton, Katherine. 2003. E-Learning Tools and Technologies: a consumer's guide for trainers, teachers, educators, and instructional designers. USA: Wiley Publising. Inc, page $12-24$

11. Hartley, E.D. 2001. Selling e-Learning. American Society for Training and Development.

12. Rusman. (2013). Belajar dan Pembelajaran Berbasis Komputer Mengembangkan Profesionalisme Guru Abad 21. Bandung: Alfabeta.

13. Tagg, J. (2007). Learning Outcomes and The Development of Expertise. On the Horizon. Vol. 15 Iss 2 pp. $89-98$

14. Sadirman A.M. (2014). Interaksi dan Motivasi Belajar Mengajar. Jakarta: Raja Grafindo Persada.

15. Tagg, J. (2007). Learning Outcomes and The Development of Expertise. On the Horizon. Vol. 15 Iss 2 pp. 89-98

16. Kettunen, J. Kairisto-Mertanen, L \&Penttilä, T. (2013). Innovation pedagogy and desired learning outcomes in higher education. On The Horizon. Vol. 21 Iss 4 pp. 333-342

17. Nagle, J.P. (2001). Voices from the margins: the stories of vocational high school students. Joseph L. DeVitis\& Linda Irwin-DeVitis (Eds). New York.: Peter Lang Publishing.

18. Clarke, L. \& Winch, C. (2007). Vocational Education: InternationalApproaches, Development and System, Oxon: Routledge

19. Hoffman, N. \&Schwartz, R. (2015). Gold Standard: The Swiss Vocational Education and Training System, International Comparative Study of Vocational Education Systems. Washington, DC: National Center on Education and the Economy

20. Clarke, L. \& Winch, C. (2007). Vocational Education: InternationalApproaches, Development and System, Oxon: Routledge

21. Gasskov, V. (2000). Managing Vocational training system. A handbook for Senior Administrators. Geneva: International Labor Office. Hoffman, N. \&Schwartz, R. (2015). Gold Standard: The Swiss Vocational Education and Training System, International Comparative Study of Vocational Education Systems. Washington, DC: National Center on Education and the Economy

22. Fjellström, M. \&Kristmansson, P. (2016). Learning as an Apprentice in Sweden: A Comparative Study on Affordances for Vocational Learning in School and Work Life Apprentice Education. Education + Training. Vol. 58 Iss 6 pp. 629-642

23. Edeling, S. \&Pilz, M. (2016). Teaching self- and SSocial Competencies in The Retail Sector Findings from Vocational Schools in Germany, Italy and Poland. Education + Training. Vol. 58 Iss 9 pp. 1041-1059

24. Gregory, S. (2011). Teaching Higher Education Students with Diverse Learning Outcomes in the Virtual World of Second Life®. In Transforming Virtual World Learning. Vol. 4 pp. 327-356. 
25. Gregory, S. (2011). Teaching Higher Education Students with Diverse Learning Outcomes in the Virtual World of Second Life®. In Transforming Virtual World Learning. Vol. 4 pp. 327-356.

26. Swandi, A. Hidayah. Irsan. (2014). Pengembangan Media Pembelajaran Laboratorium Virtual untuk Mengatasi Miskonsepsi Pada Materi Fisika Inti di SMAN 1 Binamu, Jeneponto. Jurnal Fisika Indonesia.

27. Xiao, D.Y. (2000). Experiencing the library in a panorama virtual reality environment. Library Hi Tech. Vol. 18 Iss 2 pp. 177- 184 